\title{
Hanna Liberska, Marzanna Farnicka (red.), Child of Many Worlds: Focus on the Problem of Ethnic Minorities, Peter Lang Edition, Frankfurt am Main 2014, ss. 227
}

Książka Child of Many Worlds: Focus on the Problem of Ethnic Minorities to monografia wieloautorska powstała w wyniku dwuletniej pracy naukowców zaangażowanych w projekt "How to help children from families of ethnic minorities in the adaptation to school in V4 countries?" dotyczący trudnej sytuacji, marginalizacji i wykluczania dzieci z mniejszości etnicznych w życiu szkoły i środowisk lokalnych. W projekcie uczestniczyli psycholodzy, pedagodzy, socjolodzy, prawnicy i językoznawcy z krajów Grupy Wyszehradzkiej: Uniwersytet West Bohemia z Pilzna (Czechy), Uniwersytet Mateja Bela z Bańskiej Bystrzycy (Słowacja), Uniwersytet w Debreczynie (Węgry), Uniwersytet Kazimierza Wielkiego w Bydgoszczy (Polska) i Uniwersytet Zielonogórski (Polska).

Autorzy zaangażowani w tworzenie monografii skupili się zarówno na opisie teoretycznym problemu wykluczania mniejszości etnicznych, jak i na praktycznych sposobach jego niwelowania. Analizowali oni aspekty polityczne, społeczne, kulturowe, socjalne, a także edukacyjne wykluczenia mniejszości narodowych w krajach Grupy Wyszehradzkiej. Książka zawiera ważne, przydatne, a przede wszystkim aktualne opisy praktyk pedagogicznych, badań i teorii dotyczących omawianej problematyki, jaką jest wykluczanie mniejszości etnicznych.

Monografia podzielona została na dwie części - pierwsza z nich zatytułowana: „Wellbeing and the Socio-Cultural Adaptation of Children to their Environment", w której znalazło się sześć artykułów, porusza problem adaptacji dziecka z mniejszości etnicznej w szkole, zagadnienia akulturacji oraz wybrane badania na temat mniejszości romskiej w kwestii przestępczości, a także wady i zalety współżycia różnych narodowości. Pierwszą część rozpoczyna tekst Hanny Liberskiej pt. The Wellbeing of Children: Its Source and 
How It is Affected by a Sense of Exclusion and Acculturation, który rzeczowo charakteryzuje problem adaptacji dziecka w szkole w stosunku do jego samopoczucia. Autorka analizuje źródła dobrego samopoczucia, w kontekście otoczenia, w jakim rozwija się dziecko, oraz jego warunków edukacyjnych. Kolejny jest artykuł pt. The Problem of Minorities as a Subject of Intercultural Psychology, autorstwa Věry Kosikovej i Hanny Liberskiej, dotyczący problemu mniejszości etnicznych z perspektywy psychologii międzykulturowej. Rozważania teoretyczne zostały tu zilustrowane wraz z wynikami badań przeprowadzonych wśród młodych ludzi reprezentujących mniejszości etniczne Republiki Czeskiej. W artykule zatytułowanym The Discourse of Social Exclusion and its Benefits for the Majority Lajos Hüse, Erzsébet Balogh Nóra Barnucz Mihály Fónai i Erika Zolnai wskazują ukrytą agendę problemów w procesie akulturacji. Kolejny tekst autorstwa Vácłava Holečka i Marzanny Farnickiej National Minorities with a Focus on the Roma Problem and its Historical and Socio-Psychological Aspects to (meta)analiza psychologicznych i społecznych aspektów badań dotyczących mniejszości etnicznych żyjących w różnych kręgach kulturowych, dotyczących mniejszości romskiej. Artykuł piąty, The Roma population of Small Towns, wprowadza czytelników w codzienne życie rodzin romskich z małych miast na Węgrzech. Autorzy: Mihály Fónay, Erzsébet Balogh, Nóra Barnucz, Lajos Hüse i Erica Zolnai, analizują cele i kwalifikacje edukacyjne członków rodzin romskich, działania związane z prowadzeniem przez nich gospodarstw domowych z uwzględnieniem dochodów rodziny. Dokonują także porównania zdrowia psychicznego rodzin romskich oraz rodzin z innych kultur. Zwieńczeniem pierwszej części monografii jest tekst Crime and its Victims amongst Members of Different Nationalities, w którym autorki Simona Musilová i Jana Miňhová przedstawiły analizę częstości wykroczeń w Republice Czeskiej, Polsce, Słowacji, Węgrzech i Ukrainie w zależności od pochodzenia narodowościowego. Autorki wskazują znaczenie stereotypów i uprzedzeń na powszechność wykluczania i wtórnego wiktymizowania przedstawicieli mniejszości narodowych.

Druga część monografii zatytułowana została „The Support of Children's Adaptation to School for the Prevention of Social Exclusion" i zamieszczono w niej siedem artykułów. Znajdujemy tu opis innowacyjnego własnego projektu badawczego. Jego głównym celem było stworzenie narzędzia pozwalającego na szybką przesiewową diagnozę stopnia adaptacji dzieci do środowiska szkolnego oraz poziomu ryzyka związanego z wykluczeniem społecznym w klasie. W kolejnym artykule zamieszczono metody pracy i możliwości wspierania dzieci zagrożonych odrzuceniem rówieśniczym i wykluczeniem społecznym. Pierwszy z tekstów, który niejako jest wprowadzeniem teore- 
tycznym wskazującym na aspekt szeroko rozumianego bezpieczeństwa, jest Children's Sense of Safety under Different Forms of Care at School and Where They Live, napisany przez Grażynę Gajewską. Autorka analizuje trudności w adaptacji społeczno-kulturalnej dzieci. Wskazuje także na niezbędność zaangażowania w tym procesie rodziców, nauczycieli, pracowników socjalnych i właściwych dla tego problemu instytucji. Dalej znajdujemy dociekliwy tekst pt. Possibility, Challenge or Barrier? Tasks of Public Education: The International Outlook and the Hhungarian Situation. Jego autorzy: Erika Zolnai, Erzsébet Balogh, Nóra Barnucz, Mihály Fónai i Lajos Hüse przedstawili rozpoznane i kontrolowane czynniki związane z akulturacją dzieci z mniejszości etnicznych w systemie edukacji publicznej na Węgrzech. Analizowali oni zadania systemu oświaty i oczekiwania społeczne nauczycieli oraz cele edukacji publicznej i jej skuteczność w przystosowywaniu się dzieci z mniejszości narodowych, podkreślając stopień przygotowania placówek do wykonywania tej roli. Bronislava Kasáčová i Soňa Kariková w kolejnym opracowaniu The Educational Requirements of Teacher's Assistants Working witch Roma Pupils: The Opinions of In-Service and University Teachers (a Comparison) przedstawiają wymagania edukacyjne asystentów nauczycieli zaangażowanych w edukację dzieci romskich. Autorki prezentują wyniki badań przeprowadzonych w ramach projektu rządowego "Improving the level of socialization of the Roma community by means of education systems for social and missionary workers and teacher's assistants". Znaleźć tu możemy ciekawe opinie zaangażowanych $\mathrm{w}$ realizowanie projektu asystentów. $\mathrm{W}$ artykule czwartym, pt. The Questionnaire of School Life (QSL), Marzanna Farnicka, Hanna Liberska, Věra Kosiková, Vladimira Lovasova oraz Dariusz Freundenreich prezentują oryginalne narzędzie „Kwestionariusz życia szkolnego” (QSL), który pozwala na szybkie rozpoznanie zagrożenia związanego z wykluczeniem społecznym w szkole. Wyjaśnić należy, iż taka wczesna identyfikacja dzieci zagrożonych wykluczeniem w środowisku szkolnym pozwala na skuteczniejsze i szybsze działania w kwestii poprawy poczucia przynależności do grupy rówieśniczej w szkole, a tym samym adaptacji dziecka w tym środowisku. W tekście tym przedstawiono także wyniki badania przeprowadzonego $\mathrm{z}$ wykorzystaniem QSL w polskich szkołach. Dalej, w Creativity Traning with the Use of Drawings in Counteracting Peer Rejection Urszula Gembara zaprezentowała swoje bogate doświadczenia z zastosowania treningu kreatywności jako skutecznej interwencji w celu zwalczania odrzucenia rówieśniczego. Autorka zauważa, że twórcze myślenie zapobiega sztywności wzorców poznawczych, a tym samym przeciwdziała odrzuceniu rówieśniczemu. Warunki skutecznego stosowania treningu kreatywności omawiane są w kontekście pracy indywi- 
dualnej oraz grupowej z dziećmi. Szósty z artykułów, napisany przez Tatianę Maciejewską, Art Therapy as a Mathod of Working with Children under the threat of Exclusion, także prezentuje doświadczenia pracy metodą arteterapii wśród dzieci zagrożonych wykluczeniem. Autorka wskazuje, na podstawie własnego doświadczenia zawodowego, jak poprawnie ukierunkowane działania dla dzieci i młodzieży mogą zabezpieczyć je przed wykluczeniem z grupy rówieśniczej. Tekst zamykający monografię zatytułowany został A Child of Many Worlds: A New Meaning of Acculturation. Jest to zbiór końcowych konkluzji wynikających z artykułów zawartych w tej monografii oraz analiza i integracja przedstawionych stanowisk na temat procesów akulturacji we współczesnym świecie.

Treści zawarte w omówionej książce odzwierciedlają wielopłaszczyznowy charakter zjawiska wykluczenia mniejszości etnicznych, które skłaniają do refleksji nad wciąż aktualnym problemem, jakim jest stosunek do „innych". Chociaż należymy do krajów rozwiniętych, kwestie związane z wykluczeniem mniejszości etnicznych są wciąż obecne. Autorzy monografii wskazują na potrzeby wprowadzania zmian nie tylko w systemach prawnych, ale także na konieczność stosowania w codziennym życiu szkoły programów, których celem jest integracja środowisk pochodzących z różnych kultur.

Astina Koch 